\title{
Agronomic evaluation of Rice Production Systems of Sawah Eco- technology in the Inland valley of Central Nigeria
}

\author{
*Usman ${ }^{1}$, A., Imolehin ${ }^{1}$, E.D., Tiamiyu ${ }^{1}$, S.A., Wakatsuki ${ }^{2}$, T., Ibrahim ${ }^{1}$, P.A. \\ and Wayas ${ }^{1}, \mathrm{~J}$. \\ 1. National Cereals Research Institute, Badeggi, P.M.B. 8, Bida, Niger State, Nigeria \\ 2. Faculty of Agriculture, Kinki University, Nara 631-8505, Japan
}

\begin{abstract}
In promoting increase productivity in rice production system in the Inland valley of central Nigeria, Sawah Eco-technology was introduced to rice farmers around Bida in central Nigeria. The technology involves levelled basin and improved bunding with inlet and outlet for irrigation and drainage to achieve full water control. In assessing the superiority of this technology over the conventional rice production system by the farmers, a survey in conjunction with field agronomic evaluation were conducted in rice growing communities where sawah was introduced. Three communities were chosen for the survey exercise. These are Ejeti, Emitsudadan and Shaba Maliki. Structural questionnaires were administered to all categories of farmers. That is those practicing sawah and those that are not. For the field agronomic evaluation, three rice communities where sawah was newly introduced were chosen. The communities were Musa, Army barrack and Ekpagi. In each of these communities, rice was cultivated using sawah technology and at the sametime there are those that are not cultivated using sawah. Survey results indicated that the mean field size of farmers using sawah was 1 ha while those that are not having a range of between 0.4 to 1.0 ha field sizes. Paddy yield for sawah compliance was between 2.0 to 2.4 t/ha and those of non compliance were between 1.0 to 1.7 t/ha. Agronomic evaluation indicated higher paddy yield in all the sawah fields compared to those of non sawah areas. Yields increased down the valley in all cases with the highest paddy yield of 4.6 t/ha obtained at the valley bottom of Army barrack site.
\end{abstract}

\section{Introduction}

Rice is grown in all the agro ecological zones of Nigeria yet production of this commodity cannot meet the demand in the country. Production per unit area has been declining at farmer's level (FAO, 2004). Yield is as low as $1.5 \mathrm{t} / \mathrm{ha}$ compared with the potential yield of up to $6.0 \mathrm{t} / \mathrm{ha}$ for improved rice varieties developed in Nigeria.

Therefore there is need for great concern over the degradation of soils and water resources. The technologies on the conservation and sustainable use of these resources need to be emphasized. Such technology will develop the growing environment of rice in order to conserve resources. For instance, environmentally creative technology or ecological engineering technology, such as sawah farming is not well developed or practiced in this sub region.This technology originates from Malayo Indonesian and it involves levelled basin and improved bunding with inlet and outlet for irrigation and drainage to achieve full water control.

The potentials for sawah development with numerous small water sheds existing in the flood plains and inland valleys has not be fully utilized. Farmers in the central Nigeria, especially the Nupe rice farmers rely on the traditional methods of land preparation that are acquired through experience (Hirose and Wakatsuki, 2002). This does not translate to higher rice yield. Therefore, a study with the objective of evaluating the agronomic performance of rice plant under sawah cultivation system was initiated.

\section{Materials and methods}

In assessing the superiority of this technology over the conventional rice production system by the farmers, a survey in conjunction with field agronomic evaluation were conducted in rice growing communities where sawah was introduced.

Three communities were chosen for the survey exercise. These are Ejeti, Emitsudadan and Shaba Maliki. Structural questionnaires were administered to all categories of farmers. That is those practicing sawah and those that are not.

For the field agronomic evaluation, three rice communities where sawah was newly introduced were chosen. The communities were Musa, Army barrack and Ekpagi. In each of these communities, rice was cultivated using sawah technology and at the sametime there are those that are not cultivated using sawah.

From the inland valleys toposequence in each of the rice growing community, a $10 \mathrm{~m} \times 10 \mathrm{~m}$ area were measured from chosen the valley fringe, middle and valley bottom for data collction. The fields were puddled, 
leveled and smoothening using power tiller and a leveler. High bund was then constructed surrounding each plot.

Improved three weeks old rice seedling was transplanted and spaced $20 \mathrm{~cm}$ x $20 \mathrm{~cm}$. Data were taken for yield comparison from the Sawah field in each plot and the farmer's field along the toposequence. Also from the non sawah fields belonging to farmers with traditional cultivation practice, sites from the fringes, middle and valley bottom of the toposequence were identified and marked for data collection as in the Sawah fields. Yield ons hectare basis were measured as well as weed cover for each treatment.

\section{Sawah assessment survey}

\section{Results and Discussion}

Survey result on sawah assessment of old sawah sites is shown in Table 1. Mean field size of farmers adapting sawah technology was about 1 ha, while that of non adapter's ranges from 0.4 to 1.0 ha across the rice growing communities. Paddy yield of the adopters was between 2.0 to $2.4 \mathrm{t} / \mathrm{ha}$ and that of the non adopters was between 1.0 to $1.7 \mathrm{t} / \mathrm{ha}$. With sawah technology and improved agronomic practices, a good paddy yield of above $4.0 \mathrm{t} / \mathrm{ha}$ is possible. However, the lower yield obtained by the farmers inspite of adaption of sawah technology may be attributed to the use of low farming inputs (Fashola, et.al., 2007). For paddy yields of $4 \mathrm{t} / \mathrm{ha}$ and above, high levels of farming inputs may be necessary in addition to sawah technology (Ofori, et.al., 2005).

Table 1: Mean field size and paddy yield from sawah and non sawah adapter in three rice growing communities around Bida, central Nigeria

\begin{tabular}{|lcccc|}
\hline Location & \multicolumn{2}{c|}{$\begin{array}{c}\text { Sawah status } \\
\text { Fdapter Non adapterAdapter }\end{array}$} & \multicolumn{2}{c|}{$\begin{array}{c}\text { yield t/ha } \\
\text { Non adapter }\end{array}$} \\
\hline Ejeti & 1.1 & 0.8 & 2.4 & 1.5 \\
Emitsudadan & 1.0 & 0.4 & 2.0 & 1.7 \\
Shaba Maliki & 1.0 & 1.0 & 2.4 & 1.2 \\
\hline
\end{tabular}

Field agronomic evaluation of sawah

Yield performance of rice plants on the toposequence of sawah and non sawah fields in sawah sites are shown in Figures 1. Higher grain yields were obtained from sawah field across the toposequence than non sawah fields.

Yield increases down the valley with sawah fields, while clear yield differences were not noticed with the non sawah field.

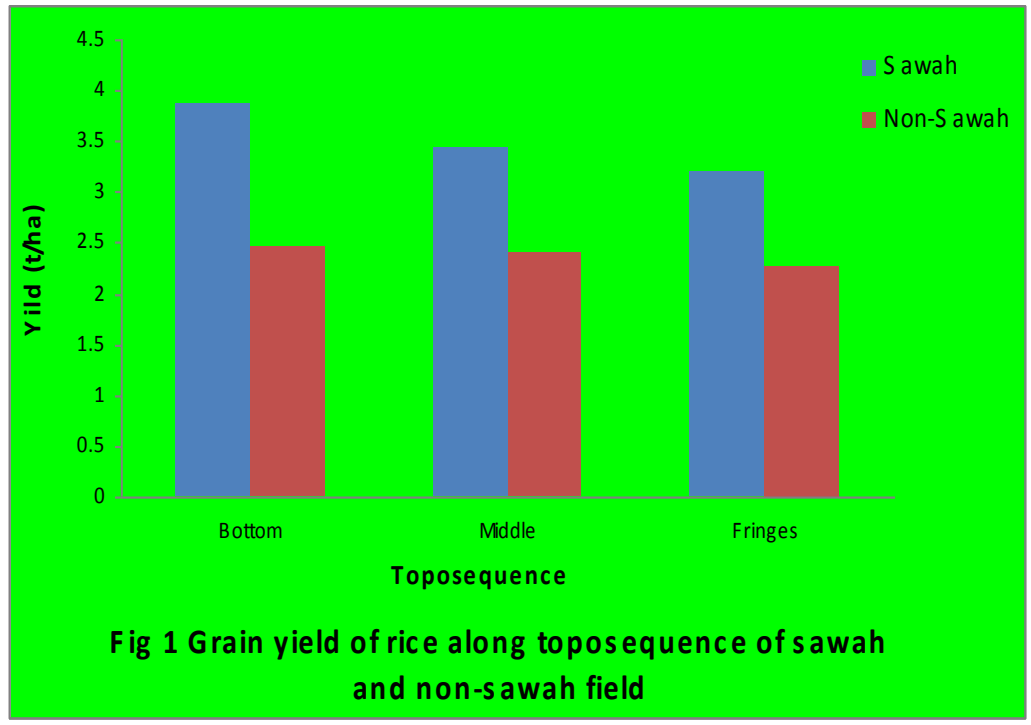


Figure 2 show weed cover score along the toposequence for sawah and non sawah fields. Weeds cover decrease along the toposequence for the sawah fields. With good water control in sawah fields, flooding of leveled field could enhanced weed control and hence less weed cover. Also accumulation of growth resources at the valley bottom enhances rapid growth and development of rice plants. This result into quick canopy formation that could smoother weed emergence in rice field.

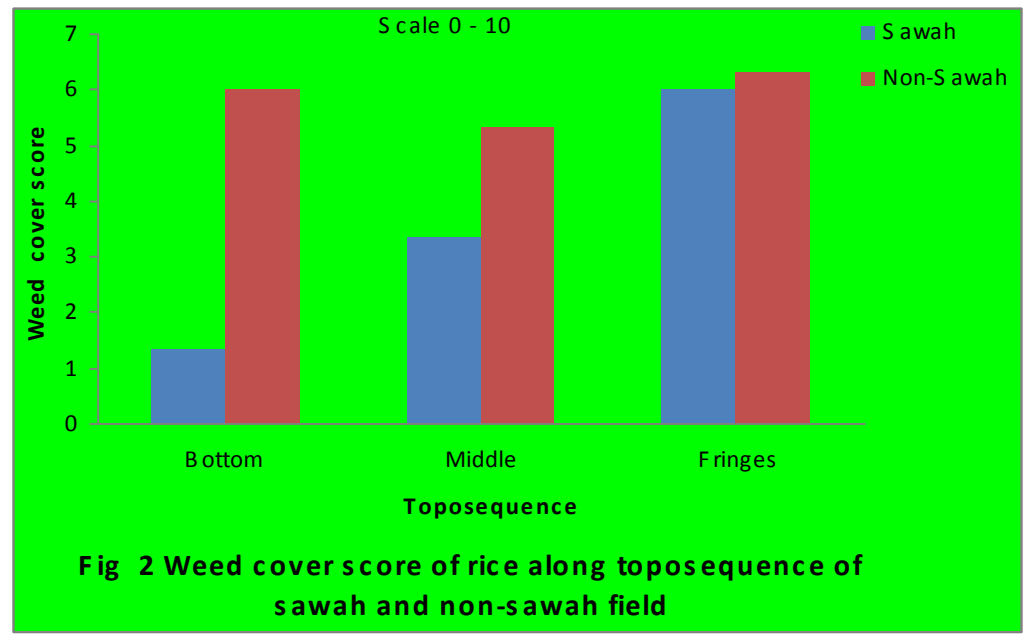

From the non sawah sites, paddy yields were generally lower than that of sawah sites (Figure 3 ). This is an indication of contribution of sawah technology to the overall yield of rice plants. This may be due mainly to the level of land preparation process, which was traditionally done using local farming implements. Smooth leveling; water control and soil nutrient distribution cannot be adequately achieved under such situation.

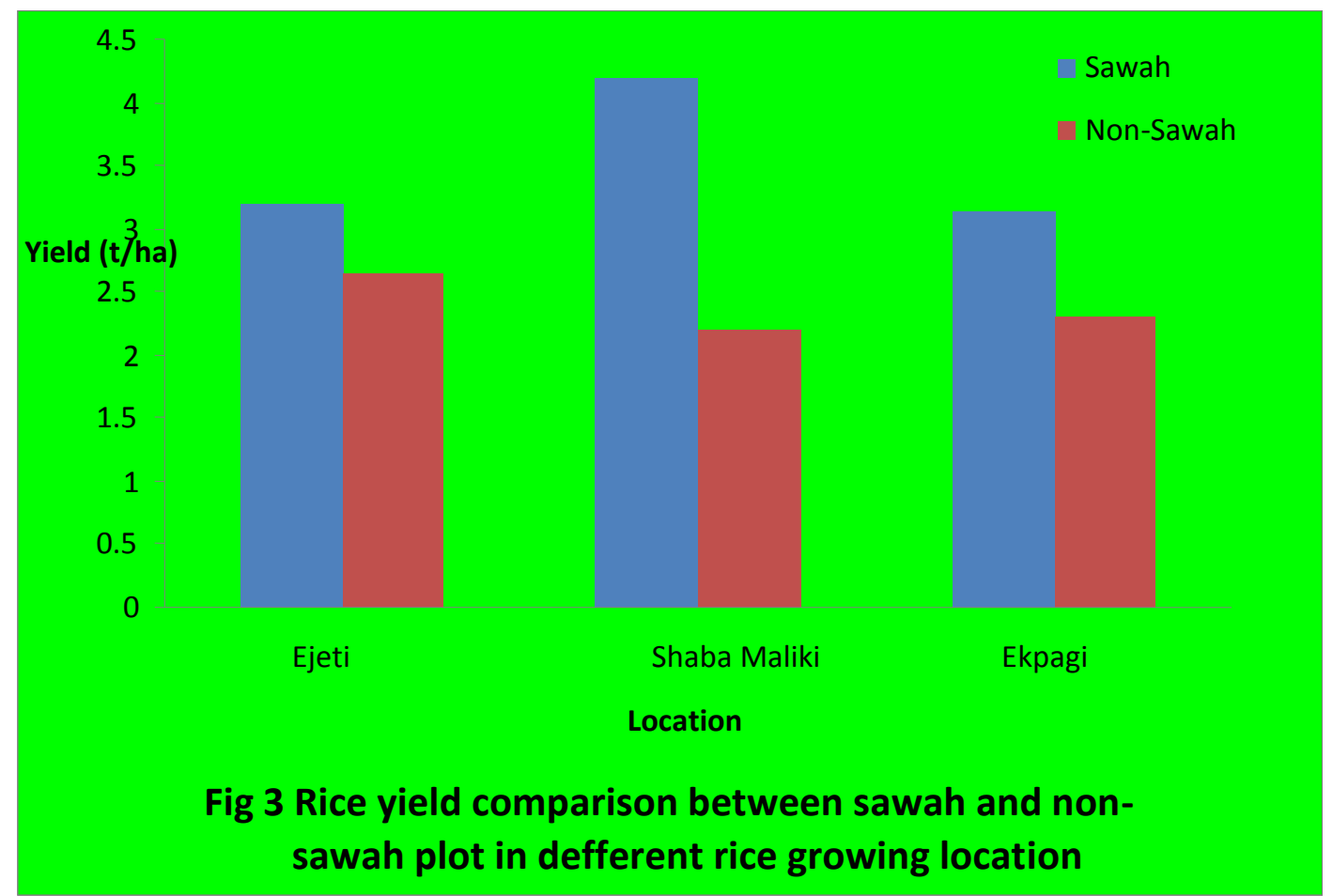

\section{Conclusion}

Sawah eco-technology has direct positive effects on rice farmers due higher paddy yields obtained from sawah fields. However, the potentials of sawah are yet to be fully tapped by the resource poor farmers around Bida environs because of their socio economic back ground. Inputs use is very low and this is presumably supposed to go along with sawah technology in order to achieve optimal paddy yield. 


\section{References}

[1]. FAOSTAT 2004: FAOSTAT Database, http://apps.fao.org

[2]. Fashola, O.O., Oladele, O., Alabi, M.O., Tologbonse, D. and Wakatsuki, T. 2007. Socio-economic factors influencing the adoption of sawah rice production technology in Nigeria. Journal of food, Agriculture and environment. JFAE, 5: 239-242

[3]. Hirose S and Wakatsuki T. 2002: Restoration of inland valley ecosystems in West African Savannah, 600 pp., Norin, Tokei Kyokai, Tokyo

[4]. Ofori, J., Hisatomi, Y., Kamidouzono, A., Masunaga, T., and Wakatsuki, T. 2005. Performance of rice cultivars in various sawah ecosystems developed in inland valleys, Asanti, Region Ghana, Soil Science plant nutrition, 51: 469-476

[5]. Wakatsuki, T. 2002. Sustainable agricultural development of West Africa during global environmental crisis. In:Restoration of inland valley ecosystems in west Africa. Hirose, S. and wakatsuki, T. (eds.), pp 1-82, Nourin,

[6]. Tokei Kyoukai, Tokyo

[7]. Wakatsuki, T. Buri, M.M. and Oladele, O. 2007. Mineralization of Africa rice green revolution by sawah eco-technology: Concept paper of new sawah project, 2007-2008.

[8]. Wakatsuki, T. and Masunsga, T. 2005. Ecological engineering for sustainable food production of degraded watersheds in tropics of low PH soils: focus on West Africa. Soil science plant nutrition 51:629-636 